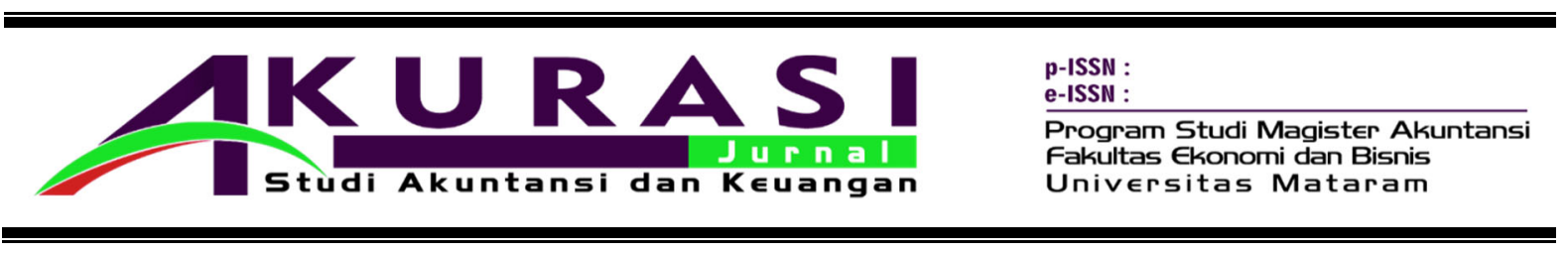

\title{
MENYIBAK TABIR PENGELOLAAN DANA DESA DARI PERSPEKTIF HABERMAS
}

\author{
Maruhun', Thatok Asmony ${ }^{2}$ \\ ${ }^{1} M T s . N W$ Teliah, maruhunarnasih@yahoo.co.id \\ 2Fakultas Ekonomi dan Bisnis Unram,tasmony@yahoo.com
}

\section{INFORMASI ARTIKEL}

Article history:

Dikirim tanggal: date

Revisi pertama tanggal: date

Diterima tanggal: date

Tersedia online tanggal $\mathrm{dd} / \mathrm{mm} / \mathrm{yyyy}$

\section{ABSTRAK}

Abstrak Penelitian ini bertujuan untuk memahami penyimpangan yang terjadi dalam pengelolaan dana desa tahun anggaran 2015 dan 2016 di Kabupaten Lombok Timur dan mengkritisi serta memperbaikinya melalui kerangka pemikiran Habermas. Jenis penelitian yang digunakan yaitu penelitian kualitatif dengan pendekatan studi kasus jenis single-case dengan multi unit analisis (embedded). Analisa data dilakukan dengan menggunakan Teori Tindakan Komunikatif Habermas. Penentuan informan menggunakan teknik purposive sampling dan selanjutnya dengan teknik snowball. Total informan yang telah diwawancarai adalah sebanyak 18 (delapan belas) orang. Hasil penelitian ini mengungkap berbagai bentuk penyimpangan pengelolaan Dana Desa (DD) yaitu proses perencanaan tidak sesuai regulasi, dominasi kepala desa dalam proses pengambilan keputusan (tidak melalui musyawarah), mark up anggaran, laporan pertanggungjawaban fiktif, pelaksanaan DD tidak melibatkan masyarakat dan pelaksanaan DD tidak transparan. Dalam pandangan Habermas rasionalisasi komunikasi yang terjadi antara pengelola dana desa dengan masyarakat adalah rasionalisasi instrumental, bukan rasionalisasi komunikatif, maka harus dilakukan tindakan komunikatif untuk mengubahnya. Dari hasil diskursus partisipan penelitian diperoleh konsensus bahwa hal paling mendasar yang terjadi dalam pengelolaan dana desa adalah tidak adanya transparansi dan tidak dilibatkannya masyarakat dalam pengelolaan dana desa. Dengan demikian perlu membentuk praksis berupa pengelolaan dana desa yang transparan dan berorientasi proses.

Kata Kunci: Dana desa, Habermas, transparansi, berorientasi proses.

\section{ABSTRACT}

The research aim at understanding the deviation accurring in village funds management in 2015 and 2016 budgeting year in East Lombok District and criticizing as well as correcting by using Habermas thinking frame. This research is qualitative research with singel case type of case study approach with multi-unit analysis (embedded). Data analysis was conducted by using Habermas Communicative Action Theory. The informants were chosen using purposive sampling technique then continued by using snowball sampling tehnique. The total number of interviewed informants was 18 (eighteen) people. The research finding reveal various kinds of deviation in village funds management in 2015 and 2016 budgeting year, causes as well as the consequences. In Habermas view of communication rationalization. The matter happening between village funds administrator and communicative was instrument rationalization, not communicative rationalization. Therefore there is a need to have a communicative action to change it. Based on participants discourse result, the concensus states that the most base matter happening in village funds management was there was no transparency and no involvoment of community in village funds management. Therefore there is a need to form a praxis in village fund management that is transparent and procces-oriented.

Keywords; Deviation, Village Funds, Habermas, transparency, processoriented 


\section{Pendahuluan}

Lahirnya Undang-Undang Nomor 6 tahun 2014 tentang desa telah membuka harapan baru bagi desa, dimana desa akan mendapatkan dana dari pemerintah dalam jumlah yang cukup besar. Namun demikian pemberian dana yang besar telah menimbulkan berbagai permasalahan, yang menyebabkan banyak kasus korupsi kepala desa sering dimuat di media. Contohnya, kasus korupsi enam kepala desa di Kabupaten Seram Bagian Timur Maluku (Frn dan Wie, 2016) dan terdapat kasus korupsi oknum kepala desa di Kabupaten Wonogiri, Jawa Tengah yang merugikan negara senilai Rp 416 juta (Krjogya, 2016). Kasus korupsi lainnya juga melibatkan oleh oknum kepala desa di Kabupaten Labuhanbatu Utara, Sumatera Utara (Harumma, 2015) serta beberapa kasus lainnya. Maraknya kasus kepala desa yang melakukan penyelewengan keuangan desa juga terjadi di Kabupaten Lombok Timur yang menjadi setting penelitian ini. Seperti kasus dugaan penyalahgunaan Alokasi Dana Desa (ADD) dan Dana Desa (DD) tahun 2015-2016 yang dilakukan oleh Kepala Desa Mendana Raya Kecamatan Keruak (Yustisi, 2017). Penyimpangan keuangan desa juga terjadi di Desa Jero Gunung Kecamatan Sakra Barat. Penyimpangan itu terjadi ketika anggaran tahun 2015 yang seharusnya digunakan untuk membangun dan merehab berbagai fasilitas desa, ternyata hingga kini belum dilaksanakan (Irwan, 2016).

Fenomena pengelolaan keuangan desa juga ditunjukkan di Desa Kertasari Kecamatan Labuhan Haji. Berdasarkan hasil wawancara awal dengan beberapa orang yang terlibat dalam pengelolaan DD di Desa Kertasari, terdapat adanya fenomena yang menarik untuk dikaji lebih dalam. Potret pengelolaan DD di Desa Kertasari ini memang belum pernah diberitakan media. Ketua Badan Permusyawaratan Desa (BPD) dan para tokoh masyarakat mengatakan, Musyawarah Rencana Pembangunan Desa (Musrenbangdes) hanya dilaksanakan sebagai formalitas saja. Pengelolaan Badan Usaha Milik Desa (BUMDes) tidak memiliki kejelasan, BUMDesnya tidak mempunyai struktur kepengurusan.

Research gap dalam penelitian ini didasari pada berbagai unsur hasil kajian. Hasil kajian peneliti terdahulu seperti Suwandi (2015), Dewanti et al. (2016), Suarnata et al. (2017), Setiawan et al. (2017), Hariyadi (2017), Indrianasari (2017) serta Mondale et al. (2017) sebagian besar dengan menggunakan paradigma positif, yang hanya sebatas melakukan pendeskripsian, interpretasi, atau usaha menghidupkan kembali sepenggal realitas dalam pengelolaan keuangan desa. Untuk mengisi research gap yang didominasi pendekatan kuantitatif, maka penelitian ini termotivasi untuk mengkaji pengelolaan DD dengan menggunakan metode studi kasus dan menganalisisnya dari perspektif Teori Tindakan Komunikatif Habermas. Argumentasi penelitian ini adalah realitas sosial bukan terjadi apa adanya tetapi diciptakan oleh interaksi sosial, sehingga penelitian ini berusaha mencari solusi dari penyimpangan yang terjadi. Fokus penelitian ini adalah mengidentifikasi permasalahan dan mengekplorasi solusi dari penyimpangan yang terjadi dalam pelaksanaan DD tahun anggaran 2015 dan 2016 di Kabupaten Lombok Timur dari perspektif Teori Tindakan Komunikatif Habermas. Berdasarkan latar belakang dan fokus penelitian, maka pertanyaan dalam penelitian ini adalah bagaimana bentuk penyimpangan dalam pengelolaan dana desa tahun anggaran 2015 dan 2016 di Kabupaten Lombok Timur dan bagaimana tindakan memperbaikinya dari perspektif Teori Tindakan Komunikatif Habermas. Oleh karena itu tujuan dari penelitian ini adalah untuk mengetahui bentukbentuk penyimpangan pelaksanaan DD tahun anggaran 2015 dan 2016 di Kabupaten Lombok Timur serta mengkritisi dan memperbaikinya melalui kerangka pemikiran Habermas.

Penelitian ini diharapkan bisa berkontribusi baik secara teoritis, praktis dan kebijakan. Agency Theory bisa untuk menjustifikasi hubungan kontraktual antara 
pemerintah, masyarakat desa sebagai prinsipal dengan kepala desa dan perangkatnya sebagai agen. Melalui teori kritis Habermas yang digunakan dalam penelitian ini diharapkan dapat memberikan pengetahuan kepada setiap orang bahwa mereka mempunyai kemampuan dan kesempatan untuk menjadi subyek dalam menciptakan perubahan keadaan yang tidak memberdayakan individu-individu. Secara praktis hasil penelitian ini diharapkan dapat menjadi referensi bagi pemerintah desa kedepannya dalam menentukan kebijakan pengelolaan keuangan desa yang berkeadilan dan mengedepankan kepentingan masyarakat dengan berpedoman pada hakekat nilai-nilai kemanusiaan. Bagi Pemerintah Kabupaten Lombok Timur hasil penelitian ini bisa menjadi masukan dalam pengambilan kebijakan yang terkait dengan pengelolaan keuangan desa. Dari aspek kebijakan, hasil penelitian ini diharapkan menjadi suatu rekomendasi baik bagi pemerintah daerah maupun pemerintah pusat dalam hal mengeluarkan kebijakan untuk mengoptimalkan implementasi Undang-Undang Nomor 6 Tahun 2014.

\section{Kerangka Teoritis}

\section{Agency Theory dan Teori Tindakan Komunikatif Habermas}

Teori keagenan (Jensen dan Meckling, 1976) sering digunakan untuk menjelaskan kecurangan akuntansi. Teori keagenan bermaksud memecahkan dua problem yang terjadi dalam hubungan keagenan. Permasalahan yang timbul akibat adanya perbedaan kepentingan antara prinsipal dan agen disebut dengan agency problems. Salah satu penyebab agency problems adalah adanya asimetri informasi. Agency Theory dalam penelitian menjustifikasikan bahwa kepala desa dalam pengelolaan DD tidak mnejalankannya sesuai dengan regulasi yang berujung pada terjadinya patologi sosial berupa penyimpangan. Kelebihan informasi yang dimiliki oleh kepala desa maupun perangkatnya yang dalam hal ini bertindak sebagai agen memang mudah dimanfaatkan untuk melakukan penyimpangan. Hal ini berpotensi terjadi karena mereka lebih mementingkan kepentingan diri sendiri dan kelompoknya, memiliki keterbatasan rasionalitas dan penghindar risiko (risk averse) sehingga mereka cenderung untuk melakukan penyimpangan.

Jurgen Habermas adalah salah seorang tokoh dari Filsafat Kritis yang dikenal dengan The Theory of Communicative Action atau Teori Tindakan Komunikatif Habermas. Rasio Komunikatif adalah tindakan berdasarkan proses musyawarah, yakni ketika dua atau lebih individu berinteraksi dan mengkoordinasikan tindakan mereka berdasarkan interpretasi dan kesepakatan terhadap situasi (Habermas, 1984: 86 dalam Nanuru, 2011). Habermas mencoba merekonstruksi psikoanalisis Freudian menjadi teori tentang komunikasi yang terdistorsi secara sistematis (McCarthy, 1982 dalam Nurhadi, 2015: 248). Pemikiran Habermas menjadi pokok perhatian didalam penelitian ini, dan digunakan sebagai perspektif pijakan dalam mengungkap dan memahami penyimpangan yang terjadi dalam pengelolaan DD.

\section{Pengelolaan Dana Desa}

Dana Desa (DD) di dalam Peraturan Pemerintah Nomor 60 Tahun 2014 tentang Dana Desa yang bersumber dari APBN, Pasal 1, ayat 2 : Dana Desa adalah dana yang bersumber dari Anggaran Pendapatan dan Belanja Negara yang diperuntukkan bagi desa yang ditransfer melalui Anggaran Pendapatan dan Belanja Daerah Kabupaten/Kota dan digunakan untuk membiayai penyelenggaraan pemerintahan, pelaksanaan pembangunan, pembinaan kemasyarakatan, dan pemberdayaan masyarakat.

Dalam Permendagri Nomor 113 Tahun 2014, pengelolaan Keuangan Desa adalah keseluruhan kegiatan yang meliputi perencanaan, pelaksanaan, penatausahaan, pelaporan, dan pertanggungjawaban keuangan desa. Tapi dirujuk dari berbagai sumber dapat disimpulkan bahwa pengelolaan keuangan desa adalah suatu proses keseluruhan kegiatan 
yang meliputi perencanaan, pelaksanaan, penatausahaan, pelaporan, dan pertanggungjawaban keuangan desa dengan memanfaatkan potensi yang ada dalam mencapai sasaran-sasaran yang telah ditetapkan dengan efektif dan efisien.

\section{Rerangka Pikir Penelitian}

Pengucuran Dana Desa dari pemerintah pusat itu dinilai memiliki sejumlah persoalan yang membuka celah terjadinya tindak pidana korupsi. Dalam hubungan kontraktual antara pemerintah, masyarakat desa dengan kepala desa dan perangkatnya merasa bahwa mereka yang paling mengetahui informasi tentang keuangan desa sehingga kelebihan informasi ini dimanfaatkan untuk melakukan penyimpangan. Hal ini sejalan dengan fokus kajian dalam Teori Keagenan. Pressure (dorongan), opportunity (kesempatan) dan rationalization (pembenaran) adalah tiga hal yang menjadi alasan seseorang melakukan penyimpangan sebagaimana yang diargumentasikan dalam Triangle Fraud Theory.

Banyaknya kasus korupsi yang melibatkan kepala desa sebagaimana yang telah diungkapkan dilatar belakang menunjukkan bahwa telah terjadi pelanggaran regulasi. Korupsi dana desa yang banyak dilakukan telah mengabaikan peran serta masyarakat dalam ikut serta berpartisipasi dalam pengelolaan DD. Dalam hubungan kontraktual antara pemerintah, masyarakat desa dengan kepala desa dan perangkatnya merasa bahwa mereka yang paling mengetahui informasi tentang keuangan desa sehingga kelebihan informasi ini berpotensi dimanfaatkan untuk melakukan penyimpangan. Hal ini sejalan dengan fokus kajian dalam Teori Keagenan.

Dari penelitian-penelitian terdahulu sebagian besar hasil penelitian menunjukkan bahwa prinsip transparansi dan akuntabilitas sudah mulai berjalan namun masih ada beberapa kendala dalam pengelolaan keuangan desa seperti faktor kompetensi dan kualitas sumber daya manusia, partisipasi masyarakat dan kurangnya pengawasan dari BPD dan masyarakat. Harus ada komunikasi sosial untuk menuju perubahan. Pemikiran Habermas tentang teori tindakan komunikatif akan mudah dipahami melalui pemahaman kita tentang dunia kehidupan dan sistem. Setiap orang berkomunikasi dan bertindak dalam sebuah dunia kehidupan, artinya ia hidup dalam sebuah alam bermakna yang dimiliki bersama komunitasnya, yang terdiri atas pandangan dunia, keyakinan moral dan nilai-nilai bersama. Rasionalisasi dunia kehidupan berarti bahwa semakin banyak bidang tidak lagi dihayati dan ditata menurut adat, tradisi dan otoritas tradisional melainkan menurut kriteria yang dapat dipertanggungjawabkan melalui diskursus (Sumaryanto, 2010).

Dengan bertolak dari pemikiran Habermas, maka peneliti ingin membentuk sebuah konstruksi pengelolaan DD yang berbasis tindakan komunikatif. Dengan adanya komunikasi yang bebas, maka dengan sendirinya akan ditemukan hal yang baik dan benar melalui proses rasionalisasi komunikatif. Rasionalisasi yang berasal dari proses diskursus semacam ini akan menghasilkan kebenaran (Hesse (1995) dalam Purnomosidi et al., 2015).

Dapat diargumentasikan bahwa pengelolaan keuangan desa belum sesuai dengan ketentuan yang ada dalam regulasi yang juga telah ditemukan dalam beberapa studi empiris. Studi Mondale et al. (2017) menemukan berbagai faktor pendukung dan penghambat dalam proses pengelolaan keuangan. Suarnata, et al. (2017) dan Suwandi (2015) menemukan kurangnya partisipasi masyarakat dalam pengelolaan ADD. Analisis analisa kritis dengan Tindakan Komunikatif Habermas adalah cara yang diharapkan bisa menyelesaikan problem yang ada sebagaimana yang sudah diargumentasikan. Berdasarkan fenomena, penelitian terdahulu dan logika berfikir peneliti dapat diargumnetasikan bahwa pengelolaan DD belum sesuai dengan prinsip-prinsip pengelolaan yang sesuai ketentuan berlaku seperti yang diharapkan. Kerangka pikir dalam penelitian disajikan secara lengkap pada gambar 1. 


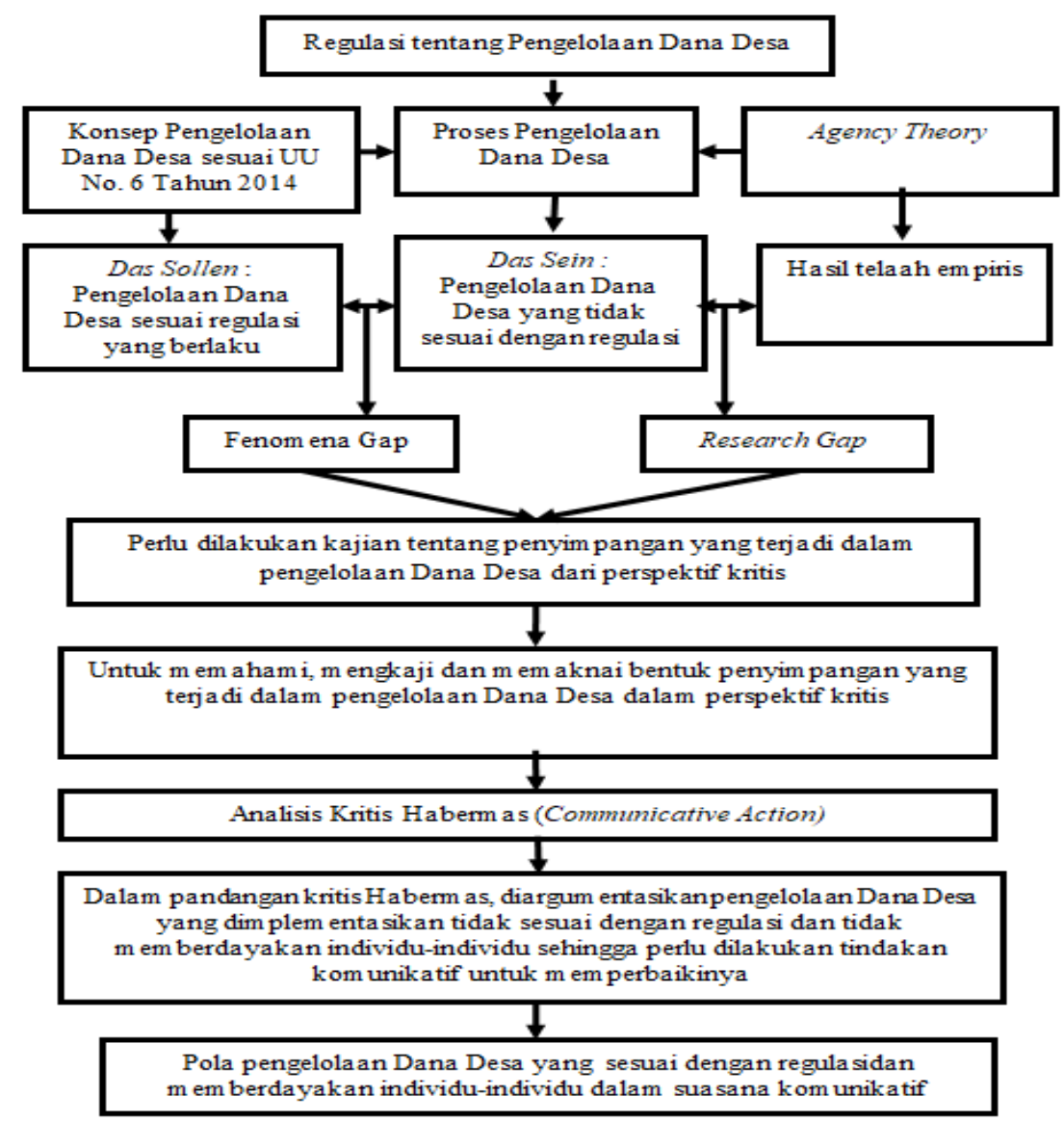

Gambar 1 . Rerangka Pikir Penelitian

\section{MetodePenelitian}

Penelitian ini menggunakan penelitian kualitatif dengan pendekatan studi kasus jenis single-case dengan multi unit analisis (embedded). Setting penelitian ini adalah desadesa di Kabupaten Lombok Timur yaitu Desa Jero Gunung di Kecamatan Sakra Barat, Desa Mendana Raya di Kecamatan Keruak dan Desa Kertasari di Kecamatan Labuhan Haji. Dipilihnya tiga desa ini karena ditengarai pengelolaan DD yang dilaksanakan oleh pemerintah desa tidak sejalan dengan prinsip-prinsip pengelolaan DD yang ideal sesuai dengan ketentuan regulasi yang ada.

Agency Theory digunakan untuk menjustifikasi hubungan kontraktual antara prinsipal dengan agen. Dalam kasus pengelolaan DD maka pemerintah dan masyarakat desa bertindak sebagai prinsipal dan kepala desa dan perangkat desa sebagai agen (Maruhun, 2017). Analisa data dilakukan dengan menggunakan Teori Tindakan Komunikatif Habermas. Secara ringkas analisis data berdasarkan Teori Tindakan Komunikatif Habermas dilakukan melalui tahapan metodologis merujuk pada Purnomosidi et al. (2015) sebagai berikut:

Tahap 1 : Identifikasi Existing System-Lifeworld (Rasionalitas Instrumental)

Tahap 2 : Menangkap Value Masyarakat (Rasionalitas Komunikatif)

Tahap 3 : Diskursus (Tindakan Komunikatif)

Tahap 4 : Membentuk Praksis.

Setelah melakukan tahap komunikasi, maka selanjutnya peneliti berusaha menyusun konsep pengelolaan DD yang dapat membebaskan dari tidak adanya komunikasi dan keterlibatan aktif masyarakat. 
Penentuan informan menggunakan teknik purposive sampling dan selanjutnya dikembangkan dengan teknik snowball sesuai dengan kebutuhan penelitian. Total informan yang telah diwawancarai adalah sebanyak 18 (delapan belas) orang. Informan kunci (keyinforman) dalam penelitian ini adalah salah seorang tokoh masyarakat yang menentang kasus penyimpangan pelaksanaan DD.

\section{Hasil dan Pembahasan}

\subsection{Temuan Hasil Penelitian}

Berdasarkan hasil telaah dokumen dan observasi lapangan serta interaksi dan interview mendalam dengan informan dapat dirumuskan beberapa temuan penelitian yang akan didiskusikan berikut ini:

\section{Perencanaan dana desa tidak sesuai Regulasi.}

Prosedur perencanaan dan pengelolaan Dana Desa (DD) tidak sesuai dengan pasal 54 UU No. 6 Tahun 2014 tentang musyawarah desa, bab VII bagian kesatu paragraf 1 PP No. 43 Tahun 2014 tentang perencanaan pembangunan desa. Selanjutnya didalam pasal 80 PP No. 43 Tahun 2014 dijelaskan siapa-siapa saja yang ikut dalam musyawarah desa. Berikut kutipan wawancara dengan informan untuk menjustifikasi temuan ini :

"Memang kan ada istilahnya Musrenbangdes. Dimulai dari Musdus (Musyawarah Dusun) sebelum Musrenbangdes.Semua elemen yang ada dalam masyarakat dilibatkan dalam perencanaan dana desa tapi hanya formalitas saja saya kira". (JN, 22 Agustus 2017).

Ungkapan informan JN dibenarkan oleh informan lainnya AM, NS dan MS pada sesi wawancara yang dilaksanakan dirumahnya.

Hasil penelitian ini sejalan dengan studi Dewanti (2016) yang menemukan bahwa masih banyak ketidaksesuaian antara perencanaan keuangan dengan perencanaan keuangan desa menurut Permendagri No. 37 Tahun 2007. Kontrakdiktif dengan temuan penelitian Indrianasari (2016) dan Setiawan et al. (2017) yang mengungkapkan bahwa pelaksanaan pengelolaan sudah sesuai dengan regulasi. Sangat berbeda dengan realita dalam penelitian ini dimana masyarakat hanya diundang sekedar formalitas saja. Mereka seolah datang hanya untuk mendengarkan pembacaan keputusan yang memang sudah dibuat sebelumnya. Masyarakat tidak bisa secara terbuka dan bebas menyampaikan pendapatnya.

\section{Dominasi Kepala Desa.}

Terdapat dominasi kepala desa dalam proses pengambilan keputusan (tidak melalui musyawarah) yang didukung oleh pernyataan informan $\mathrm{JN}$ pada sesi wawancara dirumahnya. Realita dalam penelitian ini adalah setiap pengambilan keputusan didominasi oleh kepala desa tanpa melalui musyawarah. Hal ini tentunya bertentangan dengan pasal pasal 54 UU No. 6 Tahun 2014 tentang musyawarah desa. Juga bertentangan dengan pasal 80 PP No. 43 Tahun 2014. Berikut kutipan wawancara yang menjelaskan temuan ini:
"Waktu itu saya masih aktif ikut rapat-rapat dan saya lihat memang ada pembentukan tim ganjil ini. Kalau tidak salah waktu Musrenbangdes. Ditunjuk-tunjuk saja. Dibentuk memang tapi setelah itu tidak ada kejelasannya....". (JN, 22 Agustus 2017).

Informan lain seperti US, ZK, JS, JR, BD, RD dan MS juga membenarkan sikap kepala desa yang selalu memutuskan semua hal tanpa melalui musyawarah yang mengesankan. 
Agency theory menjadi sangat relevan untuk menjustifikasi hubungan kontraktual antara pengelola DD sebagai agen dan masyarakat sebagai prinsipal. Hal ini terkait dengan permasalahan tingkat akuntabilitas dan transparansi pelaksanaan DD. Berdasarkan argumentasi Teori Keagenan dalam konteks pengelolaan DD, dominasi kepala desa dalam proses pengambilan keputusan (tidak melalui musyawarah) memberikan kesempatan yang sangat besar kepada kepala desa dalam upaya mementingkan diri sendiri (self interest). Kadang kala terdapat perbedaan kepentingan ekonomis antara principal dengan agent sehingga dapat memunculkan permasalahan agency theory (Lewaru, 2015), sebagaimana juga dalam konteks pengelolaan dana desa terjadi perbedaan kepentingan (conflict of interest) yang berpotensi terjadinya perilaku oportunistik oleh pihak yang memiliki kewenangan.

Mondale et al. (2017) menjelaskan bahwa faktor penghambat dalam pengelolaan keuangan desa adalah kurangnya partisipasi masyarakat. Menurut Hariyadi (2017) yang mencoba membandingkan pengelolaan keuangan di dua desa menyatakan bahwa sangat penting keikutsertaan masyarakat dalam setiap Musrebangdes maupun kegiatan agar sesuai dengan yang dinginkan oleh masyarakat dan dapat terciptanya transparansi karena masyarakat terlibat dalam setiap kegiatan. Suarnata, et al. (2017) dan Suwandi (2015) juga menjelaskan bahwa partisipasi masyarakat juga memiliki peranan yang penting dalam pengelolaan ADD tapi mereka menemukan partisipasi masyarakat masih kurang. Pengelola DD dalam hal ini kepala desa sebaiknya tidak mendominasi pengambilan keputusan karena akan memberikan kesan bahwa kepala desa tidak memberikan kesempatan kepada masyarakat untuk ikut berpartisipasi.

\section{Mark-up Anggaran.}

Permasalahan lain dalam pengelolaan dana desa adalah adanya mark-up anggaran. Anggaran yang ditujukan untuk pembangunan dan pemberdayaan masyarakat lebih banyak diselewengkan. Hal ini bertentangan dengan pasal 77 UU No 6 Tahun 2014 yang mengatakan pengelolaan kekayaan milik desa dilaksanakan berdasarkan asas kepentingan umum, fungsional, kepastian hukum, keterbukaan, efisiensi, efektivitas, akuntabilitas, dan kepastian nilai ekonomi. Apa yang dianggarkan di APBDesa tidak sesuai dengan realita dilapangan. Pelaksana pengelolaan DD tidak memiliki konsep yang seharusnya dimiliki oleh seorang pelayan publik.

Kutipan wawancara yang mendukung adanya mark-up anggaran diperoleh melalui wawancara, informan JN mencoba menguraikan kepala desa yang suka menggelembungkan anggaran di APBDes. Ketika peneliti konfirmasi dalam sesi wawancara berbeda, pernyataan ini dibenarkan juga oleh AY, JS, BD, RD dan MS. Hal ini berdampak pada terjadinya penyimpangan DD dalam jumlah yang cukup besar, yang hal ini bertentangan dengan PP No. 60 Tahun 2014 pasal 2. Berikut kutipan wawancara yang menjelaskan hal tersebut:

"........jumlah uang yang dikasi kepala desa ke TPK tidak sesuai dengan yang dianggarkan. Misalnya untuk rabat gang diberikan ke TPK 38 juta sedangkan yang dianggarkan 52 juta......."(JN, 22 Agustus 2017).

Hubungan keagenan yang merupakan salah satu bentuk interaksi sosial yang paling tua dan umum muncul ketika ada pemisahan fungsi pengelolaan dan fungsi kepemilikan, dimana salah satu pihak (agent) bertindak sebagai perwakilan pihak lain (principal) dalam pengambilan keputusan. Pemisahan fungsi pengelolaan dan kepemilikan akan menimbulkan agency problems karena adanya perbedaan kepentingan (Liviani et al., 2016). Perbedaan kepentingan memicu terjadinya keinginan dari pihak agen sebagai pelayan publik yang memiliki kewenangan untuk mendapatkan keuntungan yang sebesar- 
besarnya sehingga sampai menggelembungkan anggaran tanpa berfikir lebih jauh akan dampaknya terhadap masyarakat. Agen sebagai pelayan publik berpotensi melakukan tindakan opportunistik yang menguntungkan dirinya atau kelompok masyarakat tertentu.

\section{Laporan Pertanggungjawaban Fiktif.}

Ada pekerjaan yang tidak pernah dikerjakan tapi dinaikkan dalam APBDes. Ada juga pekerjaan yang dikerjakan sebagai proyek instansi lain dianggarkan lagi dalam APBDes. Setelah dilakukan konfirmasi memang peneliti mendapatkan informasi dan bukti kompeten mengenai hal ini. Ada indikasi bukti fiktif dan tidak sah dengan adanya pemalsuan tanda tangan dan pemalsuan kuitansi didalam Laporan Pertanggungjawaban. Informasi lain terkait dengan laporan Pertanggungjawaban fiktif juga peneliti peroleh dari AM, NS, DT, EL, HS, dan MS yang memberikan informasi senada. Kutipan berikut menegaskan terjadinya hal tersebut:

".........Banyak kegiatan-kegiatan fiktif yang dicantumkan dalam APBDesnya padahal dalam kenyataannya tidak ada". (JN, 22 Agustus 2017).

Adanya pertanggungjawaban fiktif ditunjukkan oleh adanya pemalsuan tanda tangan dan pemalsuan kuitansi didalam laporan pertanggungjawaban. Berdasarkan hal diatas laporan pertanggungjawaban dilaksanakan hanya sebatas untuk memenuhi ketentuan regulasi saja. Jadi, dapat dikatakan bahwa akuntabilitas pemerintah desa tidak dijalankan secara sukarela, tidak didorong untuk mempertimbangkan kepentingan stakeholder dalam laporan pertanggungjawabannya. Studi Setiawan et al. (2017) mengungkap bahwa pembuatan laporan realisasi dan SPJ sudah mengimplementasikan prinsip transparansi dan akuntabilitas. Jadi sangat berbeda dengan hasil penelitian ini dimana banyak sekali penyimpangan dari realita dalam pembuatan SPJnya. Permasalahan dalam pembuatan SPJ fiktif menunjukkan bahwa ketidaktahuan prinsipal dalam hal ini masyarakat tentang informasi keuangan yang dikerjakan oleh agen memberikan peluang bagi agen untuk membuat SPJ fiktif dengan harapan bahwa masyarakat tidak akan pernah tahu akan hal tersebut.

\section{Pelaksanaan DD tidak melibatkan Masyarakat.}

Disamping kerugian materiil penyimpangan yang terjadi juga telah menghambat proses keterlibatan partisipasi aktif masyarakat dalam tahap-tahap pengelolaan DD. Tujuan diberikannya DD untuk pembangunan dan pemberdayaan masyarakat tidak tercapai seutuhnya. Pasal 68 UU Desa telah mengatur hak dan kewajiban masyarakat desa untuk mendapatkan akses dan dilibatkan dalam pembangunan desa. Hasil wawancara dengan informan kunci (JN) yang didukung oleh informan lain seperti AM, NS, AY, DT, JS, JR, $\mathrm{RD}$ dan MS juga memberikan pernyataan yang cukup menyayangkan tentang pengelolaan DD yang tidak melibatkan masyarakat. Berikut kutipan pernyataan informan untuk menjustifikasi temuan ini :

"Semua elemen yang ada dalam masyarakat dilibatkan dalam perencanaan dana desa tapi hanya formalitas saja saya kira dan pada pelaksanaannya yang tidak melibatkan masyarakat sama sekali". (JN, 22 Agustus 2017).

Hasil penelitian ini sejalan dengan temuan penelitian Mondale et al. (2017) yang mengungkapkan bahwa partisipasi masyarakat kurang, walaupun penyebab kurangnya partisipasi itu berbeda dengan hasil penelitian ini. Kurangnya keterlibatan masyarakat dalam pengelolaan keuangan desa juga ditunjukkan oleh Setiawan et al. (2017) yang mana di saran penelitiannya mengatakan supaya merangkul masyarakat desa untuk ikut serta berperan aktif di dalam memajukan desa. Suarnata et al. (2017) menegaskan terjadinya 
kegagalan berbagai program pembangunan pedesaan di masa lalu disebabkan antara lain karena penyusunan, pelaksanaan dan evaluasi program-program pembangunan tidak melibatkan masyarakat. Hal yang penting adalah keterlibatan masyarakat dalam pengelolaan DD sehingga terwujud tujuan yang menjadi amanat dari UU desa tentang pemberian DD.

\section{Pelaksanaan Dana Desa Tidak Transparan.}

Tidak adanya keterbukaan kepala desa dalam pengelolaan DD sehingga masyarakat tidak memperoleh informasi yang seimbang dengan pihak agen dalam pengelolaan DD. Wawancara dengan JN yang diperkuat oleh pernyataan informan KS, AM, DT, JS, BD, HS, dan MS pada sesi wawancara berbeda memberikan informasi yang cukup kuat sebagaimana dinyatakan dalam kutipan berikut ini :

"Desa ini menjalankan semua kegiatannya secara tertutup tanpa ada transparansi. Semua orang yang terlibat dalam pengelolaan dana desa mulai dari BPD, LKMD sampai staf desanya adalah orang-orang yang memang bisa diajak bekerja sama, tapi bekerja sama dalam hal menyembunyikan kebobrokan kepala desanya......". (JN, 22 Agustus 2017).

Temuan penelitian ini mendukung argumentasi Setiawan et al. (2017) bahwa transparansi adalah prinsip keterbukaan yang memungkinkan masyarakat untuk mengetahui dan mendapatkan akses informasi seluas-luasnya. Lebih lanjut dijelaskan bahwa pembuatan laporan realisasi dan SPJ sudah mengimplementasikan prinsip transparansi dan akuntabilitas. Jadi sangat berbeda dengan hasil penelitian ini, dimana banyak sekali penyimpangan regulasi dalam pembuatan SPJnya. Tidak adanya transparansi dapat membuka celah terjadinya penyimpangan yang lebih luas.

\subsection{Pembahasan}

Pandangan Pandangan Teori Kritis Habermas terhadap penyimpangan pelaksanaan DD dan solusi yang dapat dilakukan didiskusikan dalam pembahasan berikut sehingga dapat diperoleh diskursus-diskurus untuk dapat merumuskan praktis bersama yang dapat mengatasi permasalahan-permasalahan dalam pengelolan dana desa. Pengambilan keputusan dalam pelaksanaan DD dalam realita penelitian ini didominasi oleh kepala desa. Setiap prosedur tidak dilaksanakan sesuai dengan regulasi. Masyarakat memang diajak untuk bermusyawarah tapi hanya untuk sekedar formalitas saja. Mereka tidak terlibat dalam setiap pengambilan keputusan. Realitas komunikasi yang seperti dalam penelitian ini menurut Habermas adalah komunikasi instrumental. Dimana kesepakatan yang didapat adalah kesepakatan semu yang sudah diarahkan. Oleh karena itu, Habermas menawarkan konsep rasional komunikatif.

Rasional Komunikatif adalah tindakan berdasarkan proses musyawarah, yakni ketika dua atau lebih individu berinteraksi dan mengkoordinasikan tindakan mereka berdasarkan interpretasi dan kesepakatan terhadap situasi (Habermas, 1984: 86 dalam Nanuru 2011). Jadi memberikan penyadaran kepada kepala desa dan orang-orang yang terlibat dalam pengelolaan DD memang perlu dilakukan sebagai solusi penyimpangan pengelolaan DD yang terjadi tapi harus dengan tindakan komunikatif bukan dengan jalan kekerasan. Komunikatif artinya berdialog dimana hanya pendapat yang terbaiklah yang bisa dijadikan sebuah kesepakatan, bukan pendapat dari orang yang dalam pandangan masyarakat memiliki kelas sosial lebih tinggi serta alasan-alasan lainnya. Melihat kenyataan yang ada sepertinya pemerintah Kabupaten Lombok Timur tidak begitu ketat dalam memberikan sanksi kepada yang melanggar aturan pengelolaan DD. Sepertinya sistem yang ada seolah memberi ruang untuk terjadinya penyimpangan. 
Peran dari Badan Permusyawaratan Desa (BPD) juga kurang optimal. BPD bahkan tidak pernah mengawasi kinerja kepala desa dalam pengelolaan DD. Didalam realitas kehidupan bermasyarakat di desa, tidak semua orang bebas untuk mengungkapkan pendapatnya karena masih ada semacam pembatasan. Penyimpangan Pengelolaan DD merupakan sebuah realitas yang mengabaikan ruang diskusi terbuka di tengah masyarakat. Secara ideal, komunikasi antar pribadi yang terdapat dalam dunia hidup harus bebas, terbuka dan tidak ada tekanan. Menurut pandangan Habermas, komunikasi yang bebas dan terbuka berarti suatu rasionalisasi dalam dunia hidup. Metode rasional akan digunakan dalam menerima konsensus.

Teori tindakan komunikatif bertujuan menciptakan momen tanpa syarat, dengan klaim validitas yang dapat dikritik, yang menyatu dengan syarat-syarat terbentuknya konsensus. Sebagai klaim mereka mengatasi semua batasan ruang dan waktu, seluruh batasan kewilayahan pada konteks tertentu (Habermas, 1981 dalam Nurhadi, 2012: 539). Realitas yang terjadi dalam pengelolaan DD memang ada kolonisasi komunikasi. Maka komunikasi inilah yang harus dibebaskan. Komunikasi dalam bentuk keterbukaan dalam berpendapat tentang pengelolaan DD. Pengelola DD harus terbuka dalam pelaksanaan DD. Mengutip ungkapan JN yang menegaskan pentingnya transparansi dalam pengelolaan dana desa sebagai berikut:

"Harus ada transparansi dalam pengelolaan dana desa. Harus terbuka dalam pengelolaannya. Jangan sampai main petak umpet. Melibatkan semua unsur dalam masyarakat dalam setiap tahap pengelolaan dana desa sehingga tercipta pengelolaan dana desa yang benar-benar bisa memberdayakan masyarakat. Jangan hanya partisipasi semu." (JN, 22 Agustus 2017).

Transparansi artinya masyarakat terlibat dalam pengelolaan. Ketika peneliti mengkonfirmasi hal ini kepada informan berinisial KS yaitu seorang kepala desa yang dilaporkan karena tuduhan korupsi DD menyampaikan argumennya terkait penyimpangan yang dilakukannya:

"Saya rasa saya tidak pernah bermaksud untuk melakukan pembodohan. Kalau dibilang saya bersalah, saya bersedia bertemu dengan masyarakat untuk bermusyawarah membahas ini. Memang saya akui kekurangan saya bahwa saya tidak melaksanakan setiap proses dalam pengelolaan dana desa sebagaimana mestinya. Tapi itu kan kekurangan saya sebagai manusia”. (KS, 24 Agustus 2017).

KS membantah bahwa dia telah melakukan pembodohan dan bersedia untuk menyelesaikan kasus penyimpangan ini dengan jalan musyawarah. Pernyataan JN menegaskan bahwa transparansi dan keterlibatan masyarakat dalam pengelolaan DD menjadi hal yang sangat penting dan selama ini terabaikan dalam praktik pengelolaan DD.

Habermas menaruh perhatian pada jenis tertentu dari komunikasi yang dia sebut sebagai argumentasi, yang didefinisikan sebagai situasi yang menempatkan partisipan dalam komunikasi yang dapat secara kritis mengkaji suatu klaim hipotesis atau validitas (Habermas, 1990: 85) dalam Tjahyadi (2003). Berdasarkan kerangka pemikiran berbasis Habermasian ini, kita dapat mengembangkan sebuah rasionalitas pentingnya keterlibatan stakeholders dalam pengelolaan DD di Kabupaten Lombok Timur, dengan menggabungkan gagasan keterlibatan stakeholder sebagai keadaan komunikasi ideal yang potensial dan mengkonseptualisasikan sistem steering dan lifeworld. Meskipun akuntansi tidak pernah secara khusus disebutkan oleh Habermas (Laughlin (1987) dalam 
Purnomosidi et.al., 2015), namun teorinya memberikan pandangan yang berguna dalam pemahaman akuntansi dan hubungannya dengan masyarakat, serta sebagai sarana penting dalam mengembangkan rekomendasi untuk perbaikan kebijakan akuntansi. Keterlibatan stakeholder dalam pandangan Habermasian, dapat dilihat sebagai bentuk transparansi dan komunikasi langsung antara organisasi dengan kelompok stakeholder mereka. Sebagai sebuah teori, teori tindakan komunikatif Habermas masih memiliki kelemahan. Teori Habermas tentunya masih bisa kita kritisi. Teori tindakan komunikatif Habermas mengasumsikan bahwa setiap orang pada dasarnya komunikatif. Padahal dalam realitanya tidak demikian karena masih banyak orang yang kesulitan untuk menyampaikan pendapatnya atau bahkan tidak mendapat/diberi ruang untuk menyampaikan pendapatnya.

Di dalam sebuah diskursus, dalam pandangan Habermas konsensus hanya bisa tercapai apabila sudah mencapai empat klaim validitas, yang salah satunya yang penting adalah kejujuran. Faktanya dalam realita kehidupan bermasyarakat, tidak semua orang memiliki kejujuran dalam mengeluarkan pendapat dan mempertimbangkan pendapat orang lain. Tapi terlepas dari hal itu, mungkin yang ingin ditonjolkan oleh Habermas adalah filosofi bahwa setiap orang memiliki kesempatan yang sama untuk berpendapat. Dari diskursus diatas maka solusi untuk menangani masalah penyimpangan dalam pengelolaan DD yaitu menerapkan pola pengelolaan DD yang transparan dan berorientasi pada proses yang melibatkan peran aktif masyarakat. Pengelolaan DD yang komunikatif dan partisipasif dituangkan dalam bentuk rembug desa untuk setiap pengambilan keputusan.

\section{Kesimpulan, Implikasi dan Keterbatasan}

Bentuk-bentuk penyimpangan dalam pelaksanaan pengelolaan Dana Desa (DD) tahun anggaran 2015 dan 2016 di Kabupaten Lombok Timur adalah berkaitan dengan: (1) prosedur perencanaan DD yang tidak sesuai regulasi (2) dominasi kepala desa dalam pengambilan keputusan (tidak melalui musyawarah) (3) mark-up anggaran (4) laporan pertanggungjawaban fiktif (5) pelaksanaan DD tidak melibatkan masyarakat serta (6) pelaksanaan pengelolaan DD tidak transparan. Berdasarkan diskursus partisipan tentang solusi perbaikannya maka dibentuklah praksis bahwa untuk memperbaiki penyimpangan pelaksanaan DD perlu dilakukan pengelolaan DD yang transparan dan berorientasi proses. Artinya ada keterbukaan dalam setiap tahap pengelolaan DD dimana masyarakat turut terlibat secara aktif didalamnya.

Secara teoritis hasil penelitian ini menjustifikasi terjadinya agency problem dalam konteks pengelolan dana desa dan teori tindakan komunikasi Habermas menjadi perspektif untuk menyelesaikan problem dalam realitas sosial. Implikasi praktik penelitian ini dapat memberikan saran bagi pemerintah Kabupaten Lombok Timur untuk memperbaiki praktik pengelolaan dana desa dengan penerapan pola pengelolaan DD yang transparan dan berorientasi pada proses dengan melibatkan partisipasi aktif masyarakat. Dalam aspek kebijakan, perlu disusun regulasi pendukung dan infrastruktur penunjang untuk sehingga pengelolaan dana desa memiliki pedoman pelaksanaan yang dapat dijadikan panduan implementasi maupun evaluasinya untuk menghindari peluang terjadinya penyimpangan dalam praktik sehingga dapat meningkatkan akuntabilitas dan transparansi pengelolaan dana desa.

Penelitian ini memiliki beberapa keterbatasan. Penelitian ini dilakukan menggunakan metode kualitatif dengan pendekatan studi kasus dimana seringkali dipandang kurang ilmiah atau pseudo-scientific karena pengukurannya bersifat subjektif. Untuk mengkonfirmasi justifikasi temuan penelitian ini, mendatang dapat dilakukan pendekatan kualitatif terkait tindakan komunikatif dalam interaksi komunikasi terhadap patologi sosial berupa penyimpangan yang terjadi dalam pengelolaan DD. Penelitian ini mengambil kasus yang sudah terjadi tapi dampaknya tetap ada sampai sekarang, sehingga 
peneliti tidak dapat terlibat langsung mengamati proses pelaksanaan pengelolaan DD, sehingga peneliti selanjutnya sebaiknya mengambil kasus yang sedang berlangsung sehingga bisa mengamati langsung proses pelaksanaan pengelolaan DD. Terakhir, tidak ada penelitian terdahulu yang membahas tentang pengelolaan keuangan desa yang menggunakan paradigma kritis dengan analisis data menggunakan Teori Tindakan Komunikatif Habermas menyebabkan peneliti tidak bisa membandingkan hasil diskursus yang berupa konsensus dapat diimplementasikan atau tidak. Penelitian mendatang dapat mengeksplorasi penelitian terdahulu yang membahas tentang pengelolaan keuangan desa yang menggunakan paradigma kritis agar bisa membandingkan hasilnya.

\section{Referensi}

Dewanti, E.D.; W. Sudarno \& T. Kurrohman. 2016. Analisis Perencanaan Pengelolaan Keuangan Desa Di Desa Boreng (Studi Kasus pada Desa Boreng Kecamatan Lumajang Kabupaten Lumajang). Jurnal Ilmiah Mahasiswa Universitas Jember, 1-6.

Hariyadi, W. 2017. Perbandingan Pengelolaan Alokasi Dana Desa di Desa Mendik dan Desa Mendik Bhakti Kecamatan Long Kali Kabupaten Paser. eJournal Pemerintahan Integrati, 5 (1), 89-98.

Indrianasari, N.T. 2017. Peran Perangkat Desa Dalam Akuntabilitas Pengelolaan Keuangan Desa (Studi Pada Desa Karangsari Kecamatan Sukodono). Jurnal Ilmiah Akuntansi Keuangan Dan Pajak, 1 (2), 29-46.

Jensen, M.C. \& W.H. Meckling. 1976. Theory of the Firm: Managerial Behavior, Agency Costs and Ownership Structure. Journal of Financial Economics 3 (4), 305-360.

Luayyi, S. 2010. Teori Keagenan dan Manajemen Laba Dari Sudut Pandang Etika Manajer. Jurnal El-Muhasaba 1(2), 199-216.

Maruhun. 2017. Village Fund Management in Perspective of Habermas Critical Theory. Proceedings of Four International Conference on Business, Economics and Social Sciences. Sekolah Tinggi Ilmu Ekonomi Jakarta (STEI) Jakarta. Edisi 4: 881-894.

McCarthy, Thomas. 1982. Teori Kritis Jurgen Habermas. (Edisi ke-5 Nopember 2015). Terjemahan oleh Nurhadi.Bantul: Kreasi Wacana.

Mondale, T.F., Aliamin. \& H. Fahlevi. 2017. Analisis Problematika Pengelolaan Keuangan Desa (Studi Perbandingan pada Desa Blang Kolak I dan Blang Kolak II, Kabupaten Aceh Tengah. Jurnal Perspektif Ekonomi Darussalam, 3 (2), 196-212.

Nanuru, R. F. 2011. Ontologi Hibua Lamo Dalam Perspektif Jurgen Habermas. Jurnal Filsafa, 21 (1), 31-47.

Peraturan Pemerintah Nomor 60 Tahun 2014 tentang Dana Desa yang bersumber dari Anggaran Pendapatan dan Belanja Negara. 21 Juli 2014. Lembaran Negara Republik Indonesia Tahun 2014 Nomor 168. Jakarta.

Peraturan Menteri Dalam Negeri Republik Indonesia Nomor 113 Tahun 2014 tentang Pengelolaan Keuangan Desa.

Peraturan Pemerintah Republik Indonesia Nomor 43 tahun 2014 tentang Peraturan Pelaksanaan Undang Undang Nomor 6 Tahun 2014. 30 Mei 2014. Lembaran Negara Republik Indonesia Tahun 2014 Nomor 123. Jakarta.

Purnomosidi, R.M., I. Triyuwono. \& A. Kamayanti. 2012. Pembebasan Etos Akuntabilitas Pelayanan Publik: Sebuah Analisis Kritis Habermas Atas Kolonisasi Lifeword. Ekuitas: Jurnal Ekonomi dan Keuangan, 19 (1), 132-152.

Runesi, S. 2010. Pertambangan Mangan Dalam Teori Kritis Jurgen Habermas (Suatu Pembacaan kritis). Jurnal Veritas, 4 (2), 1-6. 
Suwandi. 2015. Partisipasi Masyarakat Dalam Pelaksanaan Alokasi Dana Desa (ADD) Di Kantor Desa. Suka Damai Kecamatan Muara Badak Kabupaten Kutai Kartanegara. eJournal Administrasi Negara, 3 (4), 1183-1194.

Suarnata, I.W.A., A.T. Atmaja. \& N.L.G. Erni. 2017. Kurangnya Partisipasi Masyarakat Dalam Pengelolaan Alokasi Dana Desa (Studi Kasus Pada Desa Manikliyu Kecamatan Kintamani Kabupaten Bangli. eJournal S1 Ak Universitas Pendidikan Indonesia Ganesa Jurusan Akuntansi Program S1, 8 (2), 1-11.

Setiawan, M.W., A.T. Atmaja. \& N.L.G. Sulindawati. 2017. Analisis Transparansi Dan Akuntabilitas Pelaporan Alokasi Dana Desa (Studi Kasus Desa Bengkel, Kec. Busungbiu, Kab. Buleleng). eJournal S1 Ak Universitas Pendidikan Indonesia Ganesa Jurusan Akuntansi Program, 7 (1), 1-11.

Sumaryanto, Y. 2008. Ruang Publik Jurgen Habermas Dan Tinjauan Atas Perpustakaan Umum Indonesia. Tesis, Universitas Indonesia.

Tjahyadi, S. 2003. Teori Kritis Jurgen Habermas: Asumsi-Asumsi Dasar Menuju Metodologi Kritik Sosial. Jurnal Filsafat, 34 (2), 180-197.

Undang-Undang Republik Indonesia Nomor Nomor 6 tahun 2014 tentang desa. 15 Januari 2014. Lembaran Negara Republik Indonesia Tahun 2014 Nomor 7. Jakarta.

Website. Frn dan Wie. 2016. Enam kepala desa jadi tersangka dugaan korupsi dana desa. Diunduh tanggal 20 Juli 2018 (http://regional.kompas.com/read/2016/05/12 15310001)

Website. KRjogja. 2016. Oknum kades di wonogiri terbukti korupsi dana desa. Diunduh tanggal 20 Juli 2018 (http://news.okezone.com/read/2016/06/08/512/1409448/)

Website. Harrumma.2015. Korupsi dana desa kades ini dituntut tujuh tahun penjara. Diunduh tanggal 20 Juli 2018

(http://nasional.republika.co.id/berita/nasional/daerah/15/11/23/ny9r1n384)

Website. Yustisi. 2017 Kades Mendana Raya Tersangka Korupsi DD. Diunduh tanggal 1 Oktober2017(https://www.suarantb.com/pilihan.editor/2017/09/245183/KadesMenda na.Raya.Tersangka.Korupsi.DD/

Website. Irwan. 2016. Diduga Selewengkan Dana Ratusan Juta, diakses pada tanggal 1 Agustus 2017. (https://www.radarlombok.co.id/kades-jero-gunung-dilaporkanpolisi.html) 